\title{
Pengaruh Tingkat Pendidikan, Pekerjaan dan Pendapatan Orang Tua terhadap Prestasi Belajar Matematika Siswa
}

\author{
${ }^{1}$ Sirwanti, ${ }^{2}$ Aisyah Nursyam, ${ }^{3}$ Elvira Ningsi \\ ${ }^{1,2,3}$ STKIP Muhammadiyah Bone
}

\begin{abstract}
Sirwanti89@gmail.com, ichanursyam@gmail.com, elviraningsi@gmail.com
\end{abstract}
\begin{abstract}
Abstrak
Penelitian ini merupakan penelitian Ex post facto yang bertujuan untuk mengetahui deskripsi tingkat pendidikan, pekerjaan, pendapatan orang tua dam prestasi belajar serta untuk mengetahui pengaruh tingkat pendidikan, pekerjaan dan pendapatan orang tua terhadap prestasi belajar. Populasi dalam penelitian ini sebanyak 68 orang siswa dengan sampel penelitian sebanyak 68 orang siswa. Pengumpulan data yang digunakan adalah angket dan dokumentasi. Hasil penelitian ini adalah (1) Tingkat pendidikan berada pada kategori rendah dengan 20 atau 29,42\% dari 68 responden, Tingkat pekerjaan dikategorikan sedang dengan 37 atau 54,41\% dari 68 responden. Tingkat pendapatan dikategorikan sangat rendah dengan 52 atau 76,48\% dari 68 responden. Sedangkan untuk prestasi belajar matematika siswa dikategori sangat tinggi dengan 46 atau 67,6\% dari 68 responden, (2) Tidak terdapat pengaruh tingkat pendidikan orang tua dengan prestasi belajar matematika siswa kelas VIII SMPN 4 Sibulue Kabupaten Bone dengan koefisien korelasi $R_{x 1 y} 0,159$ dan koefisien determinasi $R_{x 1 y}^{2}$ sebesar $0,025, Y=81,322+0,153 X_{1}$ dengan nilai sig $0,195>0,05$; (3) Tidak terdapat pengaruh tingkat pekerjaan orang tua dengan prestasi belajar matematika siswa kelas VIII SMPN 4 Sibulue Kabupaten Bone dengan koefisien korelasi $R_{x 1 y} 0,146$ dan koefisien determinasi $R_{x 1 y}^{2} 0,021, Y=82,081+$ $0,398 \mathrm{X}_{2}$ dengan nilai sig $0,233>0,05$; (4) Terdapat pengaruh tingkat pendidikan orang tua dengan prestasi belajar matematika siswa kelas VIII SMPN 4 Sibulue Kabupaten Bone dengan koefisien korelasi $\mathrm{R}_{\mathrm{x} 1 \mathrm{y}} 0,221$ dan koefisien determinasi $\mathrm{R}_{\mathrm{x} 1 \mathrm{y}}^{2} 0,049, \mathrm{Y}=$ $86,411-0,224 \mathrm{X}_{3}$ dengan nilai sig $0,070>0,05$; (5) Tidak terdapat pengaruh tingkat pendidikan, pekerjaan, dan pendapatan orang tua secara bersama-sama dengan prestasi belajar siswa kelas VIII SMPN 4 Sibulue Kabupaten Bone dengan koefisien korelasi $\mathrm{R}_{\mathrm{x} 1 \mathrm{y}}$ 0,303 dan koefisien determinasi $\mathrm{R}_{\text {xly }}^{2} 0,092, \mathrm{Y}=82,503+0,157+0,373-0,234$ dengan nilai sig $0,101>0,05$.
\end{abstract}

Kata Kunci : Prestasi Belajar Matematika, Tingkat Pendidikan Orang Tua, Tingkat Pekerjaan Orang Tua, Tingkat Pendapatan Orang Tua

\section{PENDAHULUAN}

Pendidikan pada dasarnya adalah usaha sadar untuk menumbuhkembangkan potensi sumber daya manusia peserta didik dengan cara mendorong dan dan memfasilitasi kegiatan belajar mereka. Pendidikan dibedakan 
menjadi tiga jalur, yaitu pendidikan formal, informal dan nonformal. Selama menempuh pendidikan formal siswa diajarkan mata pelajaran sesuai dengan jenjangnya masing-masing. Setiap siswa memiliki prestasi belajar yang berbedabeda. Muhibbin Syah (Setya, 2012: 3) mengemukakan bahwa prestasi belajar adalah tingkat keberhasilan siswa mencapai tujuan yang telah ditetapkan dalam sebuah program. Banyak faktor yang mempengaruhi prestasi belajar siswa, diantaranya faktor internal dan faktor eksternal. Menurut Dalyono (Hadiyanto,2014: 172) faktor-faktor yang dapat mempengaruhi prestasi belajar diantaranya pendidikan orang tua dan besar kecilnya penghasilan orang tua. Tingkat pendidikan orang tua adalah tingkat pendidikan menurut jenjang pendidikan yang telah ditempuh, melalui pendidikan formal disekolah berjenjang dari pendidikan dasar sampai pendidikan tinggi. Sependapat dengan Dalyono, Suryabrata (Hadiyanto, 2014: 172) mengemukakan bahwa faktor-faktor yang dapat mempengaruhi prestasi belajar yang akan diraih, antara lain adalah pendidikan orang tua dan sosial ekonomi orang tua yang meliputi pekerjaan dan pendapatan orang tua. Pekerjaan orang tua adalah aktifitas/kegiatan yang dilakukan seseorang secara terus-menerus untuk mendapatkan penghasilan agar dapat memenuhi kebutuhan hidupnya yang diberi batasan sebagai pekerjaan yang berstatus tinggi, sedang dan rendah. Sedangkan tingkat pendapatan orang tua adalah tinggi rendahnya seluruh pendapatan yang diterima oleh seseorang baik yang berasal dari keterlibatan langsung dalam proses produksi atau tidak, yang dapat diukur dengan uang dan digunakan untuk memenuhi kebutuhan pada suatu keluarga dalam satu bulan dengan satuan rupiah. Tujuan dari penelitian ini adalah untuk mengetahui deskripsi tentang tingkat pendidikan, pekerjaan dan pendapatan orang tua terhadap prestasi belajar matematika siswa dan untuk mengetahui seberapa besar pengaruh tingkat pendidikan, pekerjaan dan pendapatan oang tua terhadap prestasi belajar matematika siswa kelas VIII SMP Negeri 4 Sibulue. 


\section{METODE PENELITIAN}

1. Jenis Penelitian

Jenis penelitian ini adalah penelitian kuantitatif ex post facto ditinjau dari tujuan sifatnya yaitu penelitian korelasional yang bertujuan untuk mengetahui pengaruh antara tingkat pendidikan, pekerjaan dan pendapatan orang tua terhadap prestasi belajar matematika siswa kelas VIII SMP Negeri 4 Sibulue.

2. Populasi dan Sampel

a. Populasi

Suatu penelitian perlu ditetapkan dahulu objek penelitian yang sering disebut dengan populasi. Adapun populasi dari penelitian ini adalah seluruh siswa kelas VIII SMP Negeri 4 Sibulue yang berjumlah 68 orang.

Tabel 2.1 Keadaan Populasi Penelitian

\begin{tabular}{ccc}
\hline No & Kelas & Jumlah \\
\hline 1. & VIII A & 21 Orang \\
2. & VIII B & 23 Orang \\
3. & VIII C & 24 Orang \\
\hline & Jumlah & 68 Orang \\
\hline
\end{tabular}

b. Sampel

Sampel adalah sebagian atau wakil populasi yang diteliti. Menurut Arikunto (Hikmah, 2018) Apabila populasi penelitian berjumlah kurang dari 100 maka sampel yang diambil adalah semuanya, namun apabila populasi penelitian berjumlah lebih dari 100 maka sampel dapat diambil antara 10$15 \%$ atau $20-25 \%$ atau lebih.

Berdasarkan pendapat di atas, maka teknik pengmbilan sampel yang digunakan adalah non probability sampling dimana populasi dalam penelitian ini sekaligus sebagai sampel penelitian yaitu sebanyak 68 siswa dan dikatakan sebagai sampel jenuh.

3. Instrumen Penelitian

Instrument penelitian adalah alat atau fasilitas yang digunakan oleh peneliti dalam mengumpulkan data agar pekerjaannya lebih mudah dan hasilnya lebih baik, dalam arti lebih cermat, lengkap, dan sistematis sehingga 
lebih mudah diolah. Adapun instrument penelitian yang digunakan dalam penelitian adalah sebagai berikut:

a. Angket

Angket adalah sejumlah pertanyaan tertulis yang digunakan untuk memperoleh informasi dari responden dalam arti laporan tentang pribadinya, atau hal-hal yang ia ketahui, Arikunto (Setya, 2012: 41). Angket yang digunakan dalam penelitian ini adalah angket tertutup, yakni angket yang telah dilengkapi dengan pilihan jawaban sehingga siswa hanya memberi tanda pada jawaban yang telah dipilih. Angket ini bertujuan untuk mengetahui tingkat pendidikan, pekerjaan, dan pendapatan orang tua siswa. Adapun kisikisi instrument tingkat pendidikan, pekerjaan, dan pendapatan orang tua adalah sebagai berikut:

Tabel 2.2 Kisi-kisi instrument tingkat pendidikan

\begin{tabular}{llc}
\hline \multicolumn{1}{c}{ Variabel } & \multicolumn{1}{c}{ Indikator } & Item \\
\hline Tingkat & a. Pendidikan Dasar & $1,3,7,10$, \\
Pendidikan Orang & b. Pendidikan Menengah & 16, \\
Tua & c. Pendidikan Tinggi & $19,23,26$, \\
& & 28,32 \\
\hline \multicolumn{1}{c}{ Jumlah } & & 10 \\
\hline
\end{tabular}

(Sumber : Setya, 2012)

Tabel 2.3 Kisi-kisi instrument tingkat pekerjaan

\begin{tabular}{ccc}
\hline \multicolumn{1}{c}{ Variabel } & \multicolumn{1}{c}{ Indikator } & Item \\
\hline Tingkat Pekerjaan & a. Pekerjaan yang berstatus tinggi & $4,6,8,11,13$, \\
Orang Tua & b. Pekerjaan yang berstatus sedang & $15,18,20,25$, \\
& c. Pekerjaan yang berstatus rendah & 29 \\
\hline Jumlah & & 10 \\
\hline
\end{tabular}

(Sumber : Mulyanto (Wijianto dan Farida, 2016))

Tabel 2.4 Kisi-kisi Instrumen tingkat pendapatan

\begin{tabular}{|c|c|c|}
\hline Variabel & Indikator & Item \\
\hline Tingkat & a. Sangat Tinggi, yaitu $\geq$ Rp. 3.500 .000 & $2,5,9,12$, \\
\hline \multirow{4}{*}{$\begin{array}{l}\text { Pendapatan Orang } \\
\text { Tua }\end{array}$} & b. Tinggi, yaitu antara Rp. $2.500 .000 \mathrm{~s} / \mathrm{d} \mathrm{Rp}$. & $14,17,21$, \\
\hline & 3.500 .000 & $22,24,27$, \\
\hline & $\begin{array}{l}\text { c. Sedang, yaitu antara Rp. } 1.500 .000 \mathrm{~s} / \mathrm{d} \text { Rp. } \\
2.500 .000\end{array}$ & 30,31 \\
\hline & d. Rendah, yaitu $\leq$ Rp. 1.500 .000 & \\
\hline
\end{tabular}

(Sumber : Bahrin, 2016)

Arikunto (Restih, 2016: 31) menjelaskan bahwa untuk mempermudah analisis data dari angket yang bertingkat, maka perlu diketahui skor yang 
diperoleh responden dari hasil angket yang diisi. Untuk itu perlu ditentukan kriteria penskoran sebagai berikut:

Tabel 2.5 Skor dan Alternative Jawaban Untuk Variabel Tingkat Pendidikan, Pekerjaan, dan Pendapatan Orang Tua

\begin{tabular}{cc}
\hline Alternatif Jawaban & Skor \\
\hline Jawaban A & 4 \\
Jawaban B & 3 \\
Jawaban C & 2 \\
Jawaban D & 1 \\
\hline
\end{tabular}

Untuk mengetahui kecenderungan tinggi rendahnya variabel tingkat pendidikan, pekerjaan dan pendapatan orang tua adalah menemukan pengkategorian skor yang diperoleh masing-masing variabel. Acuan pengkategorian skor adalah sebagai berikut :

Tabel 2.6 Acuan Pengkategorian Skor Variabel

\begin{tabular}{cc}
\hline Rumus & Kategori \\
\hline $\mathrm{X} \leq \mu-1,5(\sigma)$ & Sangat Rendah \\
$\mu-1,5(\sigma)<\mathrm{X} \leq \mu-0,5(\sigma)$ & Rendah \\
$\mu-0,5(\sigma)<\mathrm{X} \leq \mu+0,5(\sigma)$ & Sedang \\
$\mu+0,5(\sigma)<\mathrm{X} \leq \mu+1,5(\sigma)$ & Tinggi \\
$\mu+1,5(\sigma)<\mathrm{X} \leq$ Skor Tertinggi & Sangat Tinggi
\end{tabular}

Sumber : Azwar (Hikmah, 2018)

1) Hasil Uji Validitas Konstruk

Instrument penelitian sebelum digunakan terlebih dahulu diuji coba agar diperoleh hasil yang valid dan reliabel. Suatu alat ukur dapat mencerminkan keadaan yang sesungguhnya dari masalah yang akan diteliti.

a) Validitas Ahli

Uji validitas dilakukan oleh orang yang ahli dalam bidangnya. Berdasarkan penilaian dari kedua ahli tersebut bahwa jumlah nilai rata-rata untuk kedua validator adalah 7,1 dan jika dibagi 2 maka didapat hasil 3,55. Berdasarkan kategori validasi bahwa angket tentang pengaruh tingkat pendidikan, pekerjaan dan pendapatan orang tua terhadap prestasi belajar matematika siswa kelas VIII SMP Negeri 4 Sibulue yang berjumlah 16 soal dapat dikatakan sahih.

b) Validitas Item

Uji validitas item dilakukan dengan menggunakan program aplikasi SPSS version 25 for Windows. Teknik pengujian yang digunakan Bivariate 
Pearson (product moment pearson). Kriteria keputusannya dengan taraf signifikansi $5 \%$ atau $0,05 \%$ yaitu jika $r_{\text {hitung }}>r_{\text {tabel }}$, maka butir angket tersebut dikatakan valid atau ditandai dengan $(*)$ dan $(* *)$. Sebaliknya, jika $\mathrm{r}_{\text {hitung }}<$ $\mathrm{r}_{\text {tabel }}$ maka butir angket tersebut tidak valid. Hasil pengujian item dapat dilihat sebagai berikut.

Tabel 2.7 Hasil Validasi Item

Kisi-Kisi Instrumen Penelitian

\begin{tabular}{llcc}
\hline \multicolumn{1}{c}{ Variabel } & \multicolumn{1}{c}{ Indikator } & Item & Jumlah \\
\hline Tingkat & a. Pendidikan Dasar & $(1), 3,7,(10)$, & 6 \\
$\begin{array}{l}\text { Pendidikan Orang } \\
\text { Tua }\end{array}$ & b. Pendidikan Menengah & 16, & \\
& c. Pendidikan Tinggi & $19,23,26,(28)$, & $(32)$ \\
Tingkat Pekerjaan & a. Pekerjaan yang berstatus tinggi & $(4),(6),(8), 11$, & 2 \\
Orang Tua & b. Pekerjaan yang berstatus sedang & $(13),(15),(18)$, & \\
& c. Pekerjaan yang berstatus rendah & $20,(25)$, & $(29)$ \\
Tingkat & a. Sangat Tinggi, yaitu $\geq$ Rp. 3.500.000 & $2,5,9,12$, & 8 \\
Pendapatan Orang & b. Tinggi, yaitu antara Rp. 2.500.000 s/d & $14,17,21$, & \\
Tua & $\quad$ Rp. 3.500.000 & $(22),(24), 27$, & \\
& c. Sedang, yaitu antara Rp. $1.500 .000 \mathrm{~s} / \mathrm{d}$ & $(30),(31)$ & \\
& d. Rp. 2.500.000 & & \\
\hline
\end{tabular}

*Keterangan: (....) item yang tidak valid

2) Uji Realibilitas

Tabel 2.8 Hasil Realibilitas

Reliability Statistics

\begin{tabular}{cc}
\hline Cronbach's Alpha & N of Items \\
\hline 0.855 & 16 \\
\hline
\end{tabular}

Berdasarkan hasil perhitungan dengan menggunakan SPSS Versi 25 for windows, diperoleh hasil Cronbach's Alpha sebesar 0,855. Oleh karena itu, nilai koefisien Cronbach's Alpha 0,855 > 0,80 maka dapat disimpulkan bahwa instrument penelitian termasuk dalam kategori reliabel.

3) Dokumentasi

Dokumentasi ditujukan untuk memperoleh laporan-laporan kegiatan, foto-foto dan data yang relevan dengan penelitian yang diperoleh secara langsung dari tempat penelitian. 


\section{Teknik Pengumpulan Data}

Teknik pengumpulan data yang digunakan meliputi:

a. Angket : peneliti memberikan daftar pertanyaan yang dilengkapi dengan alternatif jawaban untuk dipilih salah satu diantaranya yang dianggap sesuai dengan kenyataannya.

b. Dokumentasi : teknik ini digunakan untuk mengumpulkan data atau informasi yang tidak bisa dilakukan melalui angket, dalam hal ini adalah nilai raport siswa.

\section{Teknik Analisis Data}

Data dalam peneitian ini dianalisis dengan menggunakan serangkaian pengujian statistik.

a. Uji Normalitas Data

Uji normalitas digunakan untuk menguji apakah data yang diperoleh berdistribusi normal atau tidak. Perhitungan dilakukan dengan bantuan komputer melalui program aplikasi SPSS. Menurut ketentuan yang ada pada program tersebut, maka kriteria dari normalitas adalah "jika p value (Sig) > 0,05 maka data berdistribusi normal. Sebaliknya jika data $\mathrm{p}$ value $(\mathrm{Sig})<0,5$ maka data berdistribusi tidak normal. Dalam hal ini digunakan metode Kolmogorov-Smirnov.

b. Uji Autokorelasi

Persamaan regresi yang baik adalah tidak memiliki masalah autokorelasi. Jika terjadi autokorelasi maka persamaan tersebut menjadi tidak baik atau tidak layak untuk diprediski. Untuk menentukan ada tidaknya autokorelasi yaitu dengan membandingkan nilai $\mathrm{DW}_{\text {hitung }}$ dengan $\mathrm{DW}_{\text {tabel }}$ pada taraf signifikan 5\%. Pengambilan keputusan sebagai berikut:

Tabel 2.9 Pengambil Keputusan Autokorelasi

\begin{tabular}{lcc}
\hline \multicolumn{1}{c}{ Hipotesis Nol } & Keputusan & Jika \\
\hline Tidak ada autokorelasi positif & Tolak & $0<\mathrm{d}<\mathrm{dl}$ \\
Tidak ada autokorelasi positif & No Decision & $\mathrm{dl} \leq \mathrm{d} \leq \mathrm{du}$ \\
Tidak ada autokorelasi negative & Tolak & $4-\mathrm{dl}<\mathrm{d}<4$ \\
Tidak ada autokorelasi negative & No Decision & $4-\mathrm{du} \leq \mathrm{d} \leq 4-\mathrm{dl}$ \\
Tidak ada autokorelasi positif atau & Tidak Ditolak & $\mathrm{du}<\mathrm{d} \leq 4-\mathrm{du}$ \\
negative & & \\
\hline
\end{tabular}

Sumber : Ghozali (Hikmah, 2018) 
c. Uji Multikolinearitas

Uji Multikolinearitas bertujuan untuk melihat apakah setiap variabel bebas berkorelasi satu sama lain atau tidak. Jika terjadi gejala multikolinearitas, maka model regresi akan bias. Dikatakan ada multikolienaritas jika nilai VIF $>10$ dan/atau nilai tolerance $<0,01$.

d. Uji Heteroskedastisitas

Uji Heteroskedastisitas digunakan untuk mengetahui ada atau tidaknya penyimpangan asumsi klasik heteroskedastisitas yaitu adanya ketidaksamaan varian dari residual untuk semua pengmatan pada model regresi. Prasayarat yang harus dipenuhi dalam model regresi adalah tidak adanya gejala heteroskedastisitas.

Analisis uji asumsi heteroskedastisitas yang digunakan pada penelitian ini adalah uji koefisien korelasi Spearman's rho yaitu dengan cara mengkorelasikan variabel independen dengan nilai unstandardized residual. Pengujian menggunakan tingkat signifikansi 0,05 dengan uji 2 sisi. Jika korelasi antara variabel independen dengan residual di dapat signifikansi lebih dari 0,05 maka dapat dikatakan bahwa tidak terjadi masalah heteroskedastisitas pada model regresi.

e. Uji Hipotesis

1) Analisis Regresi

a) Analisis regresi linier sederhana

Persamaan yang dapat dibuat dalam analisis regresi sederhana adalah sebagai berikut :

$\mathrm{Y}=\mathrm{a}+\mathrm{bX}$

(Sumber: Hikmah,

2018)

Keterangan:

Y : Variabel Terikat

X : Variabel Bebas

a : Konstanta

b : Koefisien regresi 
Untuk mengetahui pengaruh variabel bebas dengan variabel terikat dengan kriteria:

1. Jika nilai sig < probabilitas 0,05 , artinya variabel bebas berpengaruh secara signifikan terhadap variabel terikat.

2. Jika nilai sig > probabilitas 0,05 , artinya variabel bebas tidak berpengaruh signifikan terhadap variabel terikat.

b) Analisis regresi linear berganda

Analisis regresi linear berganda digunakan bila jumlah variabel independennya minimal dua. Persamaan regresi untuk tiga prediktor adalah : $Y=a+b_{1} X_{1}+b_{2} X_{2}+b_{3} X_{3}$

Keterangan:

Y : Prestasi Belajar

a : Konstanta

b : Koefisien Regresi

$\mathrm{X}_{1}$ : Tingkat Pendidikan Orang Tua

$\mathrm{X}_{2} \quad$ : Tingkat Pekerjaan Orang Tua

$\mathrm{X}_{3} \quad$ : Tingkat Pendapatan Orang Tua

( Sumber : Hikmah, 2018)

Untuk mengetahui ada tidaknya pengaruh antara variabel bebas dengan variabel terikat secara bersama-sama. Dengan criteria :

1) Jika nilai Sig <0,05, maka variabel bebas secara bersama-sama berpengaruh signifikan terhadap variabel terikat.

2) Jika nilai Sig > 0,05, maka variabel bebas secara bersama-sama tidak berpengaruh terhadap variabel terikat

2) Koefisien Determinasi

Koefisien determinasi (KD) adalah angka yang menyatakan atau digunakan untuk mengetahui kontribusi atau sumbangan yang diberikan oleh sebuah variabel atau lebih $\mathrm{X}$ (bebas) terhadap variabel terikat (Y).

Rumus: KD $=r^{2} \times 100 \%$

Keterangan:

KD : Koefisien Determinasi 
$r^{2} \quad:$ Koefisien Korelasi

(Sumber: Hikmah, 2018)

\section{HASIL PENELITIAN}

1. Statistik Deskriptif

a. Deskripsi Tingkat Pendidikan Orang Tua

Tabel 3.1 Statistik skor tingkat pendidikan orang tua siswa kelas VIII SMP Negeri 4 Sibulue Kabupaten Bone

\begin{tabular}{lc}
\hline \multicolumn{1}{c}{ Statistik } & Nilai Statistik \\
\hline Skor tinggi & 24 \\
Skor rendah & 9 \\
Rata-rata skor & 15,81 \\
Skor maksimum yang mungkin dicapai & 24 \\
Skor minimum yang mungkin dicapai & 6 \\
\hline
\end{tabular}

Sumber: SMP Negeri 4 Sibulue Kabupaten Bone Tahun Pelajaran 2019/2020

Tabel 3.2 Distribusi dan Persentase skor angket tingkat pendidikan orang tua siswa kelas VIII SMP Negeri 4 Sibulue Kabupaten Bone

\begin{tabular}{cccc}
\hline Skor & Kategori & Frekuensi & Persentase \\
\hline $19,5<X \leq 24$ & Sangat Tinggi & 12 & $17,64 \%$ \\
$16,5<X \leq 19,5$ & Tinggi & 17 & $25 \%$ \\
$13,5<X \leq 16,5$ & Sedang & 12 & $17,64 \%$ \\
$10,5<X \leq 13,5$ & Rendah & 20 & $29,42 \%$ \\
$X \leq 10,5$ & Sangat Rendah & 7 & $10,30 \%$ \\
\hline Jumlah & & 68 & $100 \%$
\end{tabular}

Sumber: SMP Negeri4 Sibulue Kabupaten Bone Tahun Pelajaran 2019/2020

Data pada tabel 3.2 menggambarkan bahwa tingkat pendidikan orang tua siswa kelas VIII SMP Negeri 4 Sibulue Kabupaten bone dikategorikan rendah. hal ini terlihat dari 68 siswa yang dijadikan responden, 12 atau $(17,64 \%)$ siswa yang tingkat pendidikan orang tuanya dikategorikan sangat tinggi, 17 atau (25\%) siswa yang tingkat pendidikan orang tuanya dikategorikan tinggi, 12 atau $(17,64 \%)$ siswa yang tingkat pendidikan orang tuanya dikategorikan sedang, 20 atau $(29,42 \%)$ siswa yang tingkat pendidikan orang tuanya dikategorikan rendah dan 7 atau (10,30\%) siswa yang tingkat pendidikan orang tuanya dikategorikan sangat rendah.-

b. Deskripi Tingkat Pekerjaan Orang Tua

Tabel 3.3 Statistik skor tingkat pekerjaan orang tua siswa kelas VIII SMP Negeri 4 Sibulue Kabupaten Bone

\begin{tabular}{lcc}
\hline & Statistik & Nilai Statistik \\
\hline Skor tinggi & & 8 \\
Skor rendah & & 2
\end{tabular}


Rata-rata skor

Skor maksimum yang mungkin dicapai

4,16

Skor minimum yang mungkin dicapai

8

Sumber: SMP Negeri 4 Sibulue Kabupaten Bone Tahun Pelajaran 2019/2020

Tabel 3.4 Distribusi dan Persentase skor angket tingkat pekerjaan orang tua siswa kelas VIII SMP Negeri 4 Sibulue Kabupaten Bone

\begin{tabular}{cccc}
\hline Skor & Kategori & Frekuensi & Persentase \\
\hline $6,5<\mathrm{X} \leq 8$ & Sangat Tinggi & 2 & $2,94 \%$ \\
$5,5<\mathrm{X} \leq 6,5$ & Tinggi & 3 & $4,41 \%$ \\
$4,5<\mathrm{X} \leq 5,5$ & Sedang & 37 & $54,41 \%$ \\
$3,5<\mathrm{X} \leq 4,5$ & Rendah & 3 & $4,41 \%$ \\
$\mathrm{X} \leq 3,5$ & Sangat Rendah & 23 & $33,83 \%$ \\
\hline
\end{tabular}

Sumber: SMP Negeri4 Sibulue Kabupaten Bone Tahun Pelajaran 2019/2020

Data pada tabel 3.4 menggambarkan bahwa tingkat pekerjaan orang tua siswa kelas VIII SMP Negeri 4 Sibulue Kabupaten bone dikategorikan sedang. Hal ini terlihat dari 68 siswa yang dijadikan responden, 2 atau $(2,94 \%)$ siswa yang tingkat pekerjaan orang tuanya dikategorikan sangat tinggi, 3 atau $(4,41 \%)$ siswa yang tingkat pekerjaan orang tuanya dikategorikan tinggi, 37 atau (54,4-1\%) siswa yang tingkat pekerjaan orang tuanya dikategorikan sedang, 3 atau $(4,41 \%)$ siswa yang tingkat pekerjaan orang tuanya dikategorikan rendah dan 23 atau $(33,83 \%)$ siswa yang tingkat pekerjaan orang tuanya dikategorikan sangat rendah.

c. Deskripsi Tingkat Pendapatan Orang Tua

Tabel 3.5 Statistik skor tingkat pendapatan orang tua siswa kelas VIII SMP Negeri 4 Sibulue Kabupaten Bone

\begin{tabular}{lc}
\hline \multicolumn{1}{c}{ Statistik } & Nilai Statistik \\
\hline Skor tinggi & 25 \\
Skor rendah & 8 \\
Rata-rata skor & 12,03 \\
Skor maksimum yang mungkin dicapai & 32 \\
Skor minimum yang mungkin dicapai & 8 \\
\hline
\end{tabular}

Sumber: SMP Negeri 4 Sibulue Kabupaten Bone Tahun Pelajaran 2019/2020

Tabel 3.6 Distribusi dan Persentase skor angket tingkat pendapatan orang tua siswa kelas VIII SMP Negeri 4 Sibulue Kabupaten Bone

\begin{tabular}{cccc}
\hline Skor & Kategori & Frekuensi & Persentase \\
\hline $26<\mathrm{X} \leq 32$ & Sangat Tinggi & 0 & $0 \%$ \\
$22<\mathrm{X} \leq 26$ & Tinggi & 2 & $2,94 \%$ \\
$18<\mathrm{X} \leq 22$ & Sedang & 4 & $5,88 \%$ \\
$14<\mathrm{X} \leq 18$ & Rendah & 10 & $14,70 \%$ \\
$\mathrm{X} \leq 14$ & Sangat Rendah & 52 & $76,48 \%$ \\
\hline
\end{tabular}

Sumber: SMP Negeri4 Sibulue Kabupaten Bone Tahun Pelajaran 2019/2020 
Data pada tabel 3.6 menggambarkan bahwa tingkat pendapatan orang tua siswa kelas VIII SMP Negeri 4 Sibulue Kabupaten bone dikategorikan sangat rendah. Hal ini terlihat dari 68 siswa yang dijadikan responden, tidak ada siswa yang tingkat pendapatan orang tuanya dikategorikan sangat tinggi, 2 atau $(2,94 \%)$ siswa yang tingkat pendapatan orang tuanya dikategorikan tinggi, 4 atau $(5,88 \%)$ siswa yang tingkat pendapatan orang tuanya dikategorikan sedang, 10 atau (14,70\%) siswa yang tingkat pendapatan orang tuanya dikategorikan rendah dan 52 atau (70,48\%) siswa yang tingkat pendapatan orang tuanya dikategorikan sangat rendah.

d. Deskripsi Prestasi Belajar Siswa

Tabel 3.7 Prestasi Belajar Siswa Kelas VIII SMP Negeri 4 Sibulue Kabupaten

\begin{tabular}{lc}
\multicolumn{2}{c}{ Bone } \\
\hline \multicolumn{1}{c}{ Statistik } & Nilai Statistik \\
\hline Skor tinggi & 95 \\
Skor rendah & 79 \\
Rata-rata skor & 83,74 \\
Skor maksimum yang mungkin dicapai & 100 \\
Skor minimum yang mungkin dicapai & 0 \\
\hline
\end{tabular}

Sumber : SMP Negeri 4 Sibulue Kabupaten Bone Tahun Pelajaran 2019/2020

Dari tabel 3.7 di atas menggambarkan prestasi belajar siswa kelas VIII SMP Negeri 4 Sibulue Kabupaten Bone. Berdasarkan pada tabel, diketahui bahwa skor tinggi yang diperoleh siswa adalah 95, skor terendah 79 dengan rata-rata skor adalah 83,73 . Skor ideal yang mungkin dicapai oleh siswa adalah 100 dan skor minimum yang mungkin dicapai adalah 0 .

Tabel 3.8 Distribusi dan Persentase Skor Prestasi Belajar Siswa Kelas VIII SMP Negeri 4 Sibulue Kabupaten Bone

\begin{tabular}{cccc}
\hline Skor & Kategori & Frekuensi & Persentase \\
\hline $81-100$ & Sangat Tinggi & 46 & $67,6 \%$ \\
$61-80$ & Tinggi & 22 & $32,4 \%$ \\
$41-60$ & Sedang & 0 & 0 \\
$21-40$ & Rendah & 0 & 0 \\
$0-20$ & Sangat Rendah & 0 & 0 \\
\hline Jumlah & & 68 & $100 \%$
\end{tabular}

Sumber: SMP Negeri 4 Sibulue Kabupaten Bone Tahun Pelajaran 2019/2020

Prestasi belajar siswa kelas VIII SMP Negeri 4 Sibulue Kabupaten Bone yang digambarkan pada tabel 3.8 dikategorikan sangat tinggi. Hal ini terlihat dari 68 siswa yang dijadikan responden, 46 atau $(67,6 \%)$ siswa yang hasil belajarnya dikategorikan sangat tinggi, 22 atau $(32,4 \%)$ siswa yang hasil 
belajarnya dikategorikan tinggi, dan tidak ada siswa yang hasil belajarnya dikategorikan sedang, rendah dan sangat rendah.

2. Statistik Infrensial

a. Uji Normalitas

Berdasarkan hasil perhitungan, dapat diketahui bahwa nilai sig hitung $=$ $0,200>\operatorname{sig}_{\text {tabel }}=0,005$ sehingga dapat disimpulkan bahwa data berdistribusi normal.

b. Uji Autokorelasi

Persamaan regresi yang baik adalah yang tidak memiliki autokorelasi. Pengujian dilakukan dengan bantuan SPSS versi 25 for windows.

\section{Tabel 3.9 Hasil uji Durbin-Watson}

\begin{tabular}{|c|c|c|c|c|c|c|c|c|c|}
\hline \multicolumn{10}{|c|}{ Model Summary } \\
\hline & & & Std. & & Chan & e Sta & tics & & \\
\hline $\mathrm{R}$ & $\begin{array}{c}\mathrm{R} \\
\text { Squa } \\
\text { re }\end{array}$ & $\begin{array}{c}\text { Adjuste } \\
\text { d R } \\
\text { Square }\end{array}$ & $\begin{array}{c}\text { the } \\
\text { Estimat } \\
\mathrm{e}\end{array}$ & $\begin{array}{c}\text { R } \\
\text { Square } \\
\text { Change }\end{array}$ & $\begin{array}{c}\text { F } \\
\text { Chan } \\
\text { ge }\end{array}$ & df1 & df 2 & $\begin{array}{c}\text { Sig. F } \\
\text { Change }\end{array}$ & $\begin{array}{l}\text { Durbin- } \\
\text { Watson }\end{array}$ \\
\hline 0,30 & 0,09 & 0,049 & 4,003 & 0,092 & 2,160 & -3 & 64 & 0,101 & 1,523 \\
\hline $3^{a}$ & & & & & & & & & \\
\hline
\end{tabular}

a. Predictors: (Constant), X3, X2, X1

b. Dependent Variable: Y

Berdasarkan hasil output di atas, diperoleh hasil DW sebesar 1,523. Jadi, $1,5164 \leq 1,523 \leq 1,700$ maka dapat disimpulkan bahwa tidak ada autokorelasi positif.

c. Uji Multikolinearitas

Berdasarkan data yang diolah dengan bantuan SPSS versi 25 for windows diketahui bahwa setiap nilai VIF lebih kecil dari 10 yaitu untuk variabel tingkat pendidikan orang tua $1,027<10$, tingkat pekerjaan orang tua $1,020<10$ dan tingkat pendapatan orang tua adalah $1,012<10$ jadi dapat disimpulkan bahwa tidak ada multikolinearitas antar variabel.

d. Uji Heteroskedastisitas

Berdasarkan perhitungan menggunakan bantuan SPSS versi 25 for windows diperoleh bahwa nilai korelasi dari ketiga variabel independen dengan Unstandardized Residual memiliki nilai signifikansi lebih dari 0,05 yaitu tingkat pendidikan orang tua $0,877>0,05$, tingkat pekerjaan orang tua 
$0,981>0,05$ dan tingkat pendapatan orang tua $0,860>0,05$. Jadi dapat disimpulkan bahwa tidak terjadi masalah heteroskedastisitas pada model regresi.

e. Uji Hipotesis

Pengujian ini bertujuan untuk mengetahui ada atau tidaknya pengaruh variabel bebas terhadap variabel terikat. Hasil penelitian ini dibantu dengan menggunakan aplikasi SPSS versi 25 for windows yang penjelasannya sebagai berikut:

1) Pengaruh tingkat pendidikan orang tua terhadap prestasi belajar matematika siswa kelas VIII SMP Negeri 4 Sibulue Kabupaten Bone

Tabel 3.10 Hasil Uji Regresi Linear Sederhana Tingkat Pendidikan

\begin{tabular}{|c|c|c|c|c|c|}
\hline \multirow[b]{3}{*}{ Model } & \multicolumn{3}{|c|}{ Coefficients $^{\mathrm{a}}$} & \multirow[b]{3}{*}{$\mathrm{t}$} & \multirow[b]{3}{*}{ Sig. } \\
\hline & \multicolumn{2}{|c|}{$\begin{array}{l}\text { Unstandardized } \\
\text { Coefficients }\end{array}$} & \multirow{2}{*}{$\begin{array}{c}\text { Standardized } \\
\text { Coefficients } \\
\text { Beta }\end{array}$} & & \\
\hline & $\mathrm{B}$ & Std. Error & & & \\
\hline 1 (Constant) & 81,322 & 1,907 & & 42,638 & 0,000 \\
\hline $\begin{array}{l}\text { TINGKAT } \\
\text { PENDIDIKAN }\end{array}$ & 0,153 & 0,117 & 0,159 & 1,310 & 0,195 \\
\hline
\end{tabular}

a. Dependent Variable: PRESTASI BELAJAR

Berdasarkan tabel diatas, diperoleh hasil pengujian $\mathrm{Y}=81,322+$ $0,153 X_{1}$. Nilai signifikansi sebesar $0,195>0,08$, nilai $R=0,159$ dan $R$ square 0,025 sehingga dapat disimpulkan bahwa tidak terdapat pengaruh yang positif dan signifikan antara tingkat pendidikan orang tua terhadap prestasi belajar matematika siswa kelas VIII SMP Negeri 4 Sibulue Kabupaten Bone.

2) Pengaruh tingkat pekerjaan orang tua terhadap prestasi belajar matematika siswa kelas VIII SMP Negeri 4 Sibulue Kabupaten Bone

Tabel 3.11 Hasil Pengujian Regresi Linear Sederhana Tingkat Pekerjaan

\section{Coefficients $^{\mathrm{a}}$}

\begin{tabular}{|c|c|c|c|c|c|}
\hline \multirow[b]{2}{*}{ Model } & \multicolumn{2}{|c|}{$\begin{array}{l}\text { Unstandardized } \\
\text { Coefficients }\end{array}$} & \multirow{2}{*}{$\begin{array}{l}\text { Standardize } \\
d \\
\text { Coefficients } \\
\text { Beta }\end{array}$} & \multirow[b]{2}{*}{$\mathrm{T}$} & \multirow[b]{2}{*}{ Sig. } \\
\hline & B & Std. Error & & & \\
\hline 1 (Constant) & 82,081 & 1,462 & & 56,125 & 0,000 \\
\hline $\begin{array}{l}\text { TINGKAT } \\
\text { PEKERJAAN }\end{array}$ & 0,398 & 0,331 & 0,146 & 1,203 & 0,233 \\
\hline
\end{tabular}

a. Dependent Variable: PRESTASI BELAJAR 
Berdasarkan tabel diatas, diperoleh hasil pengujian $\mathrm{Y}=82,081+$ $0,398 \mathrm{X}_{2}$. Nilai signifikansi sebesar $0,233>0,08$, nilai $\mathrm{R}=0,146$ dan $\mathrm{R}$ square $=0,021$ sehingga dapat disimpulkan bahwa tidak terdapat pengaruh yang positif dan signifikan antara tingkat pekerjaan orang tua terhadap prestasi belajar matematika siswa kelas VIII SMP Negeri 4 Sibulue Kabupaten Bone.

3) Pengaruh tingkat pendapatan orang tua terhadap prestasi belajar matematika siswa kelas VIII SMP Negeri 4 Sibulue Kabupaten Bone Tabel 3.12 Hasil Analisis Regresi Linear Sederhana Tingkat Pendapatan Orang Tua

\section{Coefficients $^{\mathbf{a}}$}

\begin{tabular}{|c|c|c|c|c|c|}
\hline \multirow[b]{2}{*}{ Model } & \multicolumn{2}{|c|}{$\begin{array}{l}\text { Unstandardized } \\
\text { Coefficients }\end{array}$} & \multirow{2}{*}{$\begin{array}{c}\text { Standardized } \\
\text { Coefficients } \\
\text { Beta }\end{array}$} & \multirow[b]{2}{*}{$t$} & \multirow[b]{2}{*}{ Sig. } \\
\hline & $\mathrm{B}$ & Std. Error & & & \\
\hline 1 (Constant) & 86,411 & 1,532 & & 56,387 & 0,000 \\
\hline $\begin{array}{l}\text { TINGKAT } \\
\text { PENDAPATAN }\end{array}$ & $-0,224$ & 0,121 & $-0,221$ & $-1,842$ & 0,070 \\
\hline
\end{tabular}

a. Dependent Variable: PRESTASI BELAJAR

Berdasarkan tabel diatas, diperoleh hasil pengujian $\mathrm{Y}=86,411-$ $0,224 X_{3}$. Nilai signifikansi sebesar $0,070<0,08$. Nilai $R=0,221$ dan nilai $R$ square $=0,049$ sehingga dapat disimpulkan bahwa terdapat pengaruh yang signifikan antara tingkat pendapatan orang tua terhadap prestasi belajar matematika siswa kelas VIII SMP Negeri 4 Sibulue Kabupaten Bone.

4) Pengaruh tingkat pendidikan, pekerjaan dan pendapatan orang tua terhadap prestasi belajar matematika siswa kelas VIII SMP Negeri 4 Sibulue Kabupaten Bone

Tabel 3.13 Hasil Analisis Regresi berganda

\begin{tabular}{|c|c|c|c|c|c|}
\hline \multicolumn{6}{|c|}{ ANOVA $^{\mathrm{a}}$} \\
\hline Model & $\begin{array}{c}\text { Sum of } \\
\text { Squares }\end{array}$ & Df & Mean Square & $\mathrm{F}$ & Sig. \\
\hline 1 Regression & 103,808 & 3 & 34,603 & 2,160 & $0,101^{\mathrm{b}}$ \\
\hline Residual & 1025,427 & 64 & 16,022 & & \\
\hline Total & 1129,235 & 67 & & & \\
\hline
\end{tabular}

Berdasarkan hasil analisis diperoleh nilai sig 0,101 >0,08. Hasil ini menunjukkan $\mathrm{Y}=82,503+0,157+0,373-0,234$. Nilai $\mathrm{R}=0,303$ dan nilai $\mathrm{R}$ square $=0,092$ (Lampiran 6: 115) yang berarti bahwa tidak ada pengaruh 
yang positif dan signifikan antara tingkat pendidikan, pekerjaan dan pendapatan orang tua secara bersama-sama terhadap prestasi belajar matematika siswa kelas VIII SMP Negeri 4 Sibulue Kabupaten Bone secara bersama-sama.

5) Koefisien Determinasi (KD)

Untuk mengetahui besar nilai sumbangsi pengaruh tingkat pendidikan, pekerjaan dan pendapatan orang tua terhadap prestasi belajar matematika siswa, maka digunakan rumus sebagai berikut:

$$
\begin{aligned}
\mathrm{KD} & =r^{2} \times 100 \% \\
& =0,092 \times 100 \% \\
& =9,2 \%
\end{aligned}
$$

Berdasarkan perhitungan diatas diperoleh hasil 9,2\% sehingga dapat disimpulkan bahwa besar sumbangsi pengaruh tingkat pendidikan, pekerjaan dan pendapatan orang tua dengan prestasi belajar matematika siswa adalah sebesar 9,2\%. Berdasarkan pedoman koefisien korelasi menurut Sugiyono, dengan nilai $\mathrm{R}$ 0,303 maka berada pada kategori lemah. Jadi dapat disimpulkan bahwa pengaruh tingkat pendidikan, pekerjaan dan pendapatan orang tua terhadap prestasi belajar matematka siswa adalah sangat lemah.

\section{PEMBAHASAN}

1. Pengaruh tingkat pendidikan orang tua terhadap prestasi belajar matematika siswa kelas VIII SMP Negeri 4 Sibulue Kabupaten Bone.

Hasil dari analisis menunjukkan bahwa nilai sig 0,195 > 0,05 dengan nilai $\mathrm{R}=0,159$ dan $\mathrm{R}^{2}=0,025$ sehingga $\mathrm{H}_{1}$ di tolak dan tidak terdapat pengaruh yang positif dan signifkan antara tingkat pendidikan orang tua terhadap prestasi belajar matematika siswa. Pengaruh tingkat pendidikan terhadap prestasi belajar siswa dikategorikan sangat lemah dengan sumbangsi sebesar 2,5\%. Seorang penyelidik Jerman, Prestel yang dikutip (Sitepu, 2008) telah membandingkan prestasi anakanak sekolah dasar di Jerman. Ia menghitung angka-angka raport kelas pertama, anak-anak yang berasal dari statusnya yang agak tinggi kemudian dibandingkannya dengan angka rata-rata raport anak yang berasal dari status sosial ekonominya yang rendah dimana yang termasuk status sosial ekonomi 
disini adalah mencakup pendidikan orang tua dan pekerjaannya. Sebagai hasil dari percobaan itu didapatinya bahwa prestasi anak-anak dari keluarga yang rendah status ekonominya adalah pada akhir kelas pertama lebih tinggi daripada prestasi anak-anak dari keluarga status ekonominya yang mencukupi, tetapi pada kelas kedua akhirnya bergeser.

Penelitian ini juga didukung dengan penelitian yang dilakukan oleh Wulandari, (2015) bahwa tidak adanya pengaruh antara tingkat pendidikan orang tua terhadap prestasi belajar siswa dengan $t_{\text {hitung }}<t_{\text {tabel }}$ yaitu $0,549<2,074$ dan Wulandari (2015) mengemukakan bahwa tingkat pendidikan orang tua bukan satu-satunya faktor yang mempengaruhi prestasi belajar siswa di sekolah. Prestasi belajar siswa bisa dipengaruhi oleh beberapa faktor yang saling mendukung satu sama lain.

Selain dari penelitian Wulandari (2015), hal ini juga didukung oleh penelitian yang dilakukan oleh Jumain (2010) yang mendapatkan hasil bahwa tidak terdapat pengaruh yang signifikan antara tingkat pendidikan orang tua terhadap prestasi belajar siswa dengan $r_{x 1 y}=-0,152$ dan $p<0,050$ yaitu $0,650>$ 0,050. Terakhir adalah penelitian yang dilakukan oleh Sitepu (2008) yang mengemukakan bahwa tidak ada hubungan antara tingkat prestasi anak dengan tingkat pendidikan orang tua di SMAN I Barus Jahe yang hubungan keduanya kurang erat karena nilai $\mathrm{Q}=0,27$ berada antara 0,10 dan 0,29 .

2. Pengaruh tingkat pekerjaan orang tua terhadap prestasi belajar matematika siswa kelas VIII SMP Negeri 4 Sibulue Kabupaten Bone

Hasil dari analisis menunjukkan bahwa nilai sig 0,233>0,05 dengan nilai $\mathrm{R}=0,146$ dan $\mathrm{R}^{2}=0,021$ sehingga $\mathrm{H}_{2}$ di tolak dan tidak terdapat pengaruh yang positif dan signifikan antara tingkat pekerjaan orang tua terhadap prestasi belajar matematika siswa kelas VIII SMP Negeri 4 Sibulue Kabupaten Bone. Pengaruh tingkat pekerjaan orang tua terhadap prestasi belajar matematika siswa dikategorikan sangat lemah dengan sumbangsi sebesar 2,1\%. Hal ini didukung oleh penelitian yang dilakukan oleh Sitepu (2008) bahwa tidak ada hubungan antara prestasi anak dengan pekerjaan orang tua dan hubungan keduanya kurang erat yaitu dengan membandingkan harga $\mathrm{C}$ dengan $\mathrm{C}_{\text {maks }}$ nya. Menurut Djafar 
(Nurhayati, 2016: 2) bahwa semakin sibuk orang tua dalam pekerjaan, semakin sedikit perhatian yang diberikan kepada anaknya. Jadi, dapat disimpulkan bahwa anak yang memiliki tingkat pekerjaan orang tua yang tinggi belum tentu bisa memiliki prestasi yang baik dan begitu juga sebaliknya.

3. Pengaruh tingkat pendapatan orang tua terhadap prestasi belajar matematika siswa kelas VIII SMP Negeri 4 Sibulue Kabupaten Bone

Hasil dari analisis menunjukkan bahwa nilai sig 0,07 > 0,05 dengan nilai $\mathrm{R}$ $=0,221$ dan $R^{2} 0,049$ yang berarti tidak terdapat pengaruh yang positif dan signifikan antara tingkat pendapatan orang tua terhadap prestasi belajar matematika siswa. Pengaruh tingkat pendapatan orang tua terhadap prestasi belajar siswa dikategorikan lemah dengan sumbangsi sebesar 4,9\%. Hal ini sesuai dengan penelitian yang dilakukan oleh Solihah (2017) bahwa tidak ada hubungan yang positif dan signifikan antara tingkat pendapatan orang tua dengan prestasi belajar siswa denga $\mathrm{p}=0,558>0,05$. Menurut Slameto (Sholihah, 2017: 1) mengungkapkan "keadaan ekonomi keluarga erat hubungannya dengan hasil belajar”. Anak yang sedang belajar harus terpenuhi kebutuhan pokoknya dan fasilitas belajarnya. Tetapi ketika orang tua sibuk mencari nafkah untuk kebutuhan keluarga, maka pengawasan orang tua terhadap anaknya kurang. Jadi siswa yang orang tuanya memiliki tingkat pendapatan tinggi belum tentu mendapatkan prestasi belajar yang tinggi juga, dan begitu juga sebaliknya.

4. Pengaruh tingkat pendidikan, pekerjaan dan pendapatan orang tua secara simultan terhadap prestasi belajar matematika siswa kelas VIII SMP Negeri 4 Sibulue Kabupaten Bone.

Hasil analisis menunjukkan bahwa nilai sig 0,101>0,05 dengan nilai $\mathrm{R}=$ 0,303 dan $\mathrm{R}^{2}$ 0,092 yang berarti tidak terdapat pengaruh antara tingkat pendidikan orang tua, pekerjaan orang tua dan pendapatan orang tua secara simultan terhadap prestasi belajar matematika siswa serta dikategorikan lemah dengan sumbangsi sebesar 9,2\% .Hal ini di dukung oleh penelitian yang dilakukan oleh Sitepu (2008) bahwa tidak ada hubungan antara prestasi anak dengan pekerjaan orang tua dan tingkat pendidikan orang tua dan hubungan keduanya kurang erat yaitu dengan membandingkan harga $\mathrm{C}$ dengan $\mathrm{C}_{\text {maks }}$ nya. Selain itu, hal ini juga di dukung oleh 
penelitian yang dilakukan oleh Sholihah (2017) yang mendapatkan hasil bahwa tidak terdapat hubungan positif antara tingkat pendidikan dan pendapatan orang tua dengan prestasi belajar siswa dengan angka koefisien korelasi sebesar $\mathrm{r}=$ 0,030 dengan signifikansi $\mathrm{p}=0,810$. Nilai $\mathrm{p}>0,05$ memutuskan bahwa korelasi tidak signifikan atau diputuskan bahwa Ho diterima dan Ha ditolak. Tingkat pendidikan, pekerjaan dan pendapatan orang tua hanya mempengaruhi prestasi belajar sebesar 9,2\% dan selebihnya dipengaruhi oleh variabel-variabel lain yang tidak diketahui.

\section{KESIMPULAN}

Hipotesis pertama "terdapat pengaruh yang positif dan signifikan antara tingkat pendidikan orang tua terhadap prestasi belajar siswa", tidak dapat diterima karena dengan nilai signifikansi 0,195>0,05. Hipotesis kedua, "terdapat pengaruh yang positif dan signifikan antara tingkat pekerjaan orang tua terhadap prestasi belajar siswa", tidak dapat diterima karena dengan nilai signifikansi sebesar 0,233>0,05. Hipotesis ketiga, "terdapat pengaruh yang positif dan signifikan antara tingkat pendapatan orang tua terhadap prestasi belajar siswa", tidak dapat diterima karena nilai signifikansi sebesar 0,070 >0,05. Hipotesis keempat, "terdapat pengaruh yang positif dan signifikan antara tingkat pendidikan, pekerjaan dan pendapatan orang tua secara simultan", tidak dapat diterima karena nilai sig 0,101 >0,05. Tingkat pendidikan, pekerjaan dan pendapatan orang tua hanya mempengaruhi prestasi belajar sebesar 9,2\% dan selebihnya dipengaruhi oleh variabel-variabel lain yang tidak diketahui. 


\section{DAFTAR PUSTAKA}

Bahrin. 2016. Hubungan Tingkat Pendapatan Orang Tua Dengan Prestasi Belajar Siswa Kelas VII SMP Negeri 1 Lasalimu Selatan. Skripsi. Fakultas Keguruan dan Ilmu Pendidikan. Universitas Halu Oleo Kendari.

Hadiyanto, Herman. 2014. Pengaruh Pendidikan, Pekerjaan dan Pendapatan Orang Tua Terhadap Prestasi Belajar Ekonomi Pada Siswa SMA. Jurnal Ekonomi Pendidikan Dan Kewirausahaan. Volume 2. Nomor 2.

Hikmah. 2018. Pengaruh Kreativitas Dan Gaya Belajar Terhadap Prestasi Belajar Matematika Siswa Kelas VII MTs DDI Lonrong Kecamatan Ponre Kabupaten Bone. Skripsi. STKIP Muhammadiyah Bone.

Jumain. 2010. Pengaruh Tingkat Pendidikan dan Motivasi Orang Tua terhadap Prestasi Belajar Mata Pelajaran Sosiologi Siswa Kelas XI SMA Al-Islam I Surakarta Tahun Pelajaran 2009-2010. Skripsi. Fakultas Keguruan dan Ilmu Pendidikan. UNISMUH Sebelas Maret: Surakarta.

Restih. 2012. Pengaruh Status Sosial Ekonomi Orang Tua Terhadap Prestasi Belajar Geografi Siswa Kelas X SMA Negeri 20 Konsel. Skripsi. Fakultas Keguruan dan Ilmu Pendidikan. Universitas Halu Oleo. Kendari.

Sitepu, Tiva Frimi Colexta. 2008. Hubungan Antara Prestasi Anak Terhadap Jenis Pekerjaan dan Tingkat Pendidikan Orang Tua Di SMAN 1 Barus Jahe. Tugas Akhir. Fakultas MIPA Universitas Sumatera Utara: Medan.

Solihah, Fitria Imroatus. 2017. Hubungan Tingkat Pendidikan dan Pendapatan Orang Tua dengan Prestasi Belajar Matematika Siswa Kelas VII SMPN 1 Banyakan Tahun Pelajaran 2015-2016. Jurnal. Universitas Nusantara PGRI: Kediri

Sumanto. 2014. Statistika Terapan. Yogyakarta: CAPS ( Center of academic publishing service)

Syah Muhibbin. 2013. Psikologi Belajar. Jakarta: PT Raja Grafindo Persada.

2014. Psikologi Pendidikan Dengan Pendekatan Baru. Bandung: PT Remaja Rosdakarya.

Wahab, Rohmalina. 2015. Psikologi Belajar. Jakarta: PT Rajagrafindo Persada.

Wijianto, Ika Farida Ulfa. 2016. Pengaruh Status Sosial dan Kondisi Ekonomi Keluarga terhadap Motivasi Bekerja Bagi Remaja Awal ( Usia 12-16 Tahun) di Kabupaten Ponorogo. Al-Tijarah. Vol 2. No.2. ISSN : 2460-4089. 190-210.

Wulandari, Desi. 2015. Pengaruh Tingkat Pendidikan Orang Tua terhadap Prestasi Belajar Siswa Kelas V Di SDN Negeri 1 Jagoan Tahun Pelajaran 2014/2015. Naskah Publikasi. Fakultas Keguruan dan Ilmu Pendidikan. UNISMUH: Surakarta. 